\title{
Language Attitude and Language Choice towards English by the Second Year Students of English Education Study Program of Palangka Raya University
}

\author{
Linda Astuti ${ }^{1^{*}}$ \\ ${ }^{1}$ The Study Program of English Education, Faculty of Teacher Training and Education \\ University of Palangka Raya
}

\begin{abstract}
This research was conducted to investigate students' language attitude and language choice to know the language use of the students in learning English. The method used in this research was descriptive qualitative. The sample was taken from the second year students of English Education Study Program of Palangka Raya University in academic year 2019/2020. The data were collected through online questionnaire and structured interview which was designed to find out the students responses related to their language attitude on English and the language choice on certain variables such as setting, gender, participant, and topic. The result showed that the students committed to the positive attitude on English which was shown through their statement in either questionnaire responses or interviews. The students argued that English is important to be mastered, and they also committed to the importance of using English in classroom activities and in verbal communication of the formal contexts. In academic environment contexts, the students mostly used English as the main language but outside of the context they were more comfortable to use Bahasa Indonesia and even local languages.
\end{abstract}

Keywords: language attitude, language choice, sociolinguistics in language teaching.

\section{INTRODUCTION}

In the growth of English use, study English becomes one of essential ability required for self-development, travel abroad, job requirement, and resume higher study. Due to those factors, English becomes the first foreign language formally teach in Indonesia. Brown (2000: 163) defines that second language learners' benefit from positive attitudes and negative attitudes may lead to increase or decrease motivation of learning. Nevertheless, he believes negative attitudes can be changed and must be changed. When someone learns a language and his language attitude is positive, the attitude will be followed by a good action and indicate a good result in studying the language. But if the language attitude is negative it will be followed by negative action that will inhibit the learning process.

According to Holmes and Wilson (2017: 404), language attitude in the context of language learning is defined as the way people look at the language, the class and the people, and the culture of language. They believe that people develop attitudes towards languages which reflect their views about those who speak the language and the context and function with which they are associated. Relating to this research, language attitude is an encouragement from individuals related to the belief, emotions, conception, and tendency that emphasize to behavior especially in language object. The language attitude is normally in line between act and thought.

\footnotetext{
*Corresponding author: lindaastutio7@yahoo.co.id

To cite this article: Astuti, L. (2021). Language Attitude and Language Choice on English by the Second Year Students of English Education Study Program of Palangka Raya University. Ebony --- Journal of English Language Teaching, Linguistics, and Literature, 1 (1) 2021, pp. 60--68.
} 
In other words, a person who learns a language (in this case, English) and has positive attitude towards the language, will have positive thought to the language itself such as speaking the language frequently, praising the language, and so on. According to Allport as cited in Baker (1992: 11) attitude is as a mental or neutral state of readiness, shaped through experience or dynamic influence on the response provided by an individual to situations and objects. Attitude is a mental position which usually manifests in the behavior or action form in the reality. In other word, attitude is about what people think and act toward something. It is a pattern of behavior, tendency or anticipatory readiness, predisposing to conform in social situations.

In relation to language attitude, Holmes and Wilson (2017: 404) state language attitude in the context of language learning is defined as the way people look at the language, the class and the people, and the culture of language. They believe that people develop attitudes towards a language which reflect their views about those who speak the language, and the contexts and functions with which they are associated.

Meanwhile, Lambert (1967: 91) states that the language attitude is consisted of three components, namely cognitive components, affective components, and conative components. Cognitive components relate to the knowledge of the environment and the idea that is usually a category used in the thought process. The affective component concerns a matter of good, like or dislike judgment, to something or a state, that the person is said to have a positive attitude. Otherwise, it is called having a negative attitude. Meanwhile, the conative component concerns behaviour or deed as the "final verdict" of a reactive readiness for a state.

Therefore, a positive attitude helps learners maintain their language skills after classroom instruction is over (Gardner, 1985). He also states a positive attitude might spur learners to interact with native speakers, which in turn increases the amount of input that learners receive. A positive attitude often leads learners to facilitate skill development in language learning. Such language attitude will lead students to give their best effort to learn the target language, so they will get opportunity to have success learning in specific language skills such as listening, speaking, reading and writing.

In this research, positive attitude can be based on three parts, such as knowing the importance of mastering English skills; knowing the importance of using English in the classroom activities and verbal communication; being confident to use English in the classroom activities and verbal communication with friends and lecturers.

In contrast, negative attitude, according to Gardner (1985) is the attitude followed with negative thought and action. It means the people do not have enthusiastic and desire to maintain the independence of the language. They may be resistant in using the language when they have negative attitudes. Negative attitude and lack of motivation can lead to obstacles in learning a language. So, the students who have negative attitude to the language will give bad impact in achievement of the target language.

In this research, negative language attitude can be based contrastly to the positive attitude, such as not knowing the importance of mastering English skills; not knowing the importance of using English in the classroom activities and verbal communication, and not being confident to use English in the classroom activities and verbal communication with 
friends and lecturers. However, student's negative attitude can be changed and turned into positive ones and be facilitated to get a positive result.

Furthermore, to know the response of the students in learning English, this research not only observe the students' language attitude but also the students' language choice. Language choice is defined as the language variety or code utilized by a particular speech community for a particular purpose or function in verbal interaction (Fishman, 1972: 95). It is essentially an action or behavior in using selected language based on the available situation. Language choice is essentially an action or behaviour in using selected language based on the available situation (Bernstain, 2003: 103). Individual sometimes has to make a choice of which language to use for some situations and it depends on the interlocutors who are also constrained by their own linguistics repertoires.

Coulmas (2013: 142) explains that people make linguistics choices for various purposes. Individual and groups choose words, registers, style and language to fulfil their various needs about communication of ideas, associations with and separation from others, domination or defiance of domination. People have ability to adapt their linguistic repertoire to new situations and build their language for specific purpose. In other words, language choice is a process of choosing a code according to some factors such as language, dialect, variation and style that used in social interaction. So, anyone who chooses the language in his community is actually applying his communicative competence or is showing his communicative performance.

As an attitude, the choice of language is essentially an action or behaviour in using selected language based on available situation. However, for this research, the term 'language choice' is used practically to refer to language attitude for its communicative performance even though language attitude contains a boarder range of understanding and applying. Thomson (2001: 170) identifies three main factors that lead to language choice selected, including situations and settings, such as time and place; participants in interactions, such as age, gender, occupations, socioeconomic status, ethnic background, and their role in relations with other participants; and conversation topics, which can be in the form of formal or informal situation or events.

Language attitude and language choice have been studied by some researchers. Dweik and Qawar (2015: 231), for instance, find that Quebec as a multilingual multicultural community offers a great field for studying language situations. The Canadian Arabs of Quebec, who live in this multilingual community, are able to choose Arabic, English, or French according to the situation they find themselves in. Their choice is triggered by several factors like purpose, topic, and preference. Arabs of Quebec have positive attitudes towards Arabic, English and French. Their attitudes towards Arabic are positive, emotional, and stem from ethnic pride; whereas their attitudes towards English and French are positive because they see that these languages express their Canadian identity and are required in several important domains in the province of Quebec.

In addition, Dewi and Setiadi (2018: 114), find that the Indonesian college students hold the positive attitude toward English. It is shown through the statement of the majority of the students who argue that English is an international language and offers more career opportunities. Their language choice is triggered by the role of the lecturers and language 
exposure in the academic environment. English is used for writing and reading. But for speaking, most of them still prefer to use Indonesian. Again, English is mostly used to talk to lecturers in academic environments based on the certain participant and setting observation,. Instead, by other participant and setting the students still prefer to use Bahasa Indonesia.

Meanwhile, Fitriati and Wardani (2019: 112) investigated language attitude and language choice among Indonesian students that they have positive language attitude towards Indonesian, English, and local languages because they are needed for their study, daily life, international communication, and future life. Indonesian is more dominant for the language choice since it is the lingua franca in Indonesia which is not as dominant as English and local languages to be used.

To be related with this research, the researcher is intended to find out the language attitude and the language choice by the university students of studying English as their major of study.

\section{METHOD}

The researcher used descriptive qualitative method by examining the phenomenon from participants of the research in order to get deeper understanding and information which are looked into. The researcher used a questionnaire and an interview as the research instrument to reveal language attitude on English and the language choice between native languages and the foreign language. The respondents of this research were 30 students of the second year students of English Education Study Program of Palangka Raya University. They are still active in studying at the English Education Study Program. The questionnaire was constructed to find out students' responses related to their language attitude and language choice. There were ten questions of questionnaire respectively asked to answer for language attitude and language choice. In addition, the structured interview was conducted by the researcher through voice-note on Whatsapp. Five questions are asked related to the language attitude and the language choice.

Furthermore, responses from the respondent are analyzed based on variables such as gender, residence (urban/ non-urban), respondents' mother tongue, and local language mastery. Language attitude is measured by Likert scale, a measurement of the attitude scale composed of statements by five point scales (1) strongly agree, (2) agree, (3) neither agree nor disagree, (4) disagree, and (5) strongly disagree. These five scales are used to express how many percent the respondents agree or disagree with a particular statement questioned on the questionnaire.

\section{RESULTS}

The following is the result of questionnaire responded by students in relation to language attitude. 
Table 1. Questionnaire of Language Attitude

\begin{tabular}{rl|r|r|r|r|r}
\hline $\mathbf{N o}$ & \multicolumn{1}{c|}{ Respondents' statements } & \multicolumn{1}{c|}{$\boldsymbol{A} \boldsymbol{A}$} & $\boldsymbol{A O D}$ & $\boldsymbol{D}$ & $\boldsymbol{S} \boldsymbol{D}$ \\
\hline $\mathbf{1}$ & English is important language to be mastered. & 14 & 16 & - & - & - \\
\hline $\mathbf{2}$ & Learning English just wasting time. & - & - & 2 & 13 & 15 \\
\hline $\mathbf{3}$ & I am confident using English. & 3 & 18 & 8 & 1 & - \\
\hline $\mathbf{4}$ & I wish I could speak fluent and accurate English. & 23 & 6 & 1 & - & - \\
\hline $\mathbf{5}$ & English is a difficult language to be learnt. & - & 3 & 23 & 4 & - \\
\hline $\mathbf{6}$ & English is needed for my future life. & 18 & 12 & - & - & - \\
\hline $\mathbf{7}$ & $\begin{array}{l}\text { Use English in daily activities will help me to } \\
\text { master the language. }\end{array}$ & 21 & 9 & - & - & - \\
\hline $\mathbf{8}$ & $\begin{array}{l}\text { I use English because I will get punishment from } \\
\text { the lecturers if I do not. }\end{array}$ & - & 3 & 8 & 8 & 11 \\
\hline $\mathbf{9}$ & $\begin{array}{l}\text { Speak English in classroom activities will } \\
\text { improve my English skills. }\end{array}$ & 19 & 11 & - & - & - \\
\hline $\mathbf{1 0}$ & $\begin{array}{l}\text { I feel uncomfortable when I listen my friends } \\
\text { speak English. }\end{array}$ & - & 4 & 6 & 11 & 9 \\
\hline
\end{tabular}

Note : $\quad S A=$ Strongly Agree $; A=$ Agree $; A O D=$ Neither Agree Nor Disagree;

$D=$ Disagree $; S D=$ Strongly Disagree

Based on the table 1, 100\% of the participants positively respond the statement of the important of English to be mastered. No one disagree or doubt with it. In terms of statement that learning English is just wasting time, most of the participants strongly disagree and disagree, and only $6.7 \%$ who are in doubt with the statement. Then, being confident in using English, 70\% of the participants positively respond the statement, and $26.7 \%$ of them still in doubt neither agree nor disagree, and only $3.3 \%$ who disagreed with the statement. The fourth statement of questionnaire asking respondents' attitude in using English by the hope that they could speak English fluently and accurately. The data in this statement showed $96.7 \%$ of the participants positively support this statement, and only $3.3 \%$ of them were still in doubt neither they agreed nor disagreed. Then, to state English is difficult, $13.3 \%$ of the participants disagreed with the statement, in contrast with $76.7 \%$ chose neither agree nor disagree, and only $10 \%$ of them agree with the statement. This depicts that students' attitude seems to be neutral.

The other five statements to show respondents' attitude in using English, for instance, English is needed for their future life; $100 \%$ of the participants positively support this statement. So, no one disagree or in doubt with it. This is also relevant with the use of English in daily life that will help them to master the language in which $100 \%$ of the participants positive with this statement as well. However, when the statement related to that they will get punishment from the lecturers if they do not use English, $72 \%$ of respondents strongly disagree and disagree. And, only $10 \%$ respondents agree with the statement which are fewer than respondents chose in neutral by $26.7 \%$.

Meanwhile, to state that speaking English in classroom activities will improve English skill; all respondents by $100 \%$ positively support this statement which means their 
responses are in agreements. Also, the attitude of feeling uncomfortable when listening friends speaking English; 66.7\% respondents deny this statement, 20\% neutral, and only $13.3 \%$ of them who agree with this. This means mostly respondents are positive about listening anyone to speak English.

In relation to the result of language choice, table 2 is the description from the questionnaire.

Table 2. Questionnaire of language choice

\begin{tabular}{|c|c|c|c|c|}
\hline Variables & Data & English & $\begin{array}{c}\text { Bahasa } \\
\text { Indonesia }\end{array}$ & $\begin{array}{c}\text { Local } \\
\text { languages }\end{array}$ \\
\hline \multirow{3}{*}{ Settings } & Inside classroom & 19 & 11 & - \\
\hline & Outside classroom & 2 & 20 & 8 \\
\hline & Social media & 15 & 15 & - \\
\hline \multirow{2}{*}{ Gender } & Male & 3 & 21 & 6 \\
\hline & Female & 3 & 23 & 4 \\
\hline \multirow{2}{*}{ Participants } & Lecturers & 25 & 5 & - \\
\hline & Friends & 5 & 19 & 6 \\
\hline \multirow{2}{*}{ Topics } & Formal & 21 & 9 & - \\
\hline & Informal & 4 & 20 & 6 \\
\hline
\end{tabular}

The researcher divided the language choice into four variables which were setting, gender, participants, and topic. On the setting variable, the participants mostly used English inside classroom and only $36.7 \%$ of them still used Bahasa Indonesia but no one used local languages. Outside classroom, most of the participants used Bahasa Indonesia, only $6.7 \%$ of them who still used English, and $26.7 \%$ of them used local languages. Whereas on social media, the participants shared to use English by half, and the other half used Bahasa Indonesia, but no one use local languages.

On the gender variable, there is no significant difference between male and female of using English. Only 10\% female used English, most of them by $76.7 \%$ used Bahasa Indonesia, and the rest $13.3 \%$ useing local languages. In similar, only $10 \%$ male used English, most of them by $70 \%$ using Bahasa Indonesia, and the rest by $20 \%$ using local languages. Relating with participant variable, when the respondents talk with their lecturers, $83.8 \%$ of them using English, and only 16.2\% using Bahasa Indonesia and none using local languages. In contrast, when respondents talking with friends only $16.7 \%$ of them using English, and $63.3 \%$ using Bahasa Indonesia, while the rest is to use local languages. Last, on the topic variable, mostly respondents by $70 \%$ tend to use English in formal while only $30 \%$ using Bahasa Indonesia. On the contrary, less respondents or $13.3 \%$ of them using English in informal topic, and most of them by $66.7 \%$ using Bahasa Indonesia while the rest by $20 \%$ using local languages.

\section{DISCUSSION}

To confirm and to assure the result of the questionnaire, the researcher analysed students' responses from the structured interview on the WhatsApp voice note. There has been found that the students admit the importance of learning English depicted by the reason "because 
English is a tool of communication and the international language. I think if I master English it will make me easier to get a better occupation or needed for my future". Furthermore, the students have awareness to use English in verbal communication and classroom activities, but only few of them use it outside the classroom activities. Afterward, the students know the importance of using English in verbal communication and classroom activities in which $63.3 \%$ they use English inside classroom and $83.8 \%$ they use English with their lecturers.

As students of English program, they actually do not have confidence to use English in verbal communication and classroom activities but they want to try their best to do it. This is depicted by the statement of the participant from the interview which state "Hmm, I think I am still nervous but I try my best to speak English fluently and I try to be confident in front of my friends, in front of people when I want to talk or I want to share my opinions or I want to talk some ideas by English language". In other words, the students show positive attitude on English in verbal communication and classroom activities. However, even the students know practice makes perfect, very few of them using English outside the classroom. It proves that environment influence the language choice of the students.

In addition, on the setting variable, there are $63.3 \%$ of the students use English inside classroom, this is confirmed by a participant via interview that states "I use English in my campus when I speak with my lecturers, and when I follow speaking class and also when I have to do presentation in my campus." This is why only $36.7 \%$ of the students use Bahasa Indonesia, and none using local languages inside classroom since it is not usual to do such thing. By the outside classroom, $66.7 \%$ of the students use Bahasa Indonesia which is also relevant with a participant said on the interview in which "I often use Bahasa Indonesia or may be local languages, just following the language spoken outside the classroom or for the informal topics".

Meanwhile, in social media 50\% of the students use English since most students admit in the interview that "I often use English when I write caption or other ideas on my social media". However, some also admit in the interview that "Honestly I still use Bahasa Indonesia for the most caption or status to write down". However, none use local languages on the social media. On the gender variable, surprisingly it does not influence the language choice since there is no difference between both to share language use; either English or Bahasa Indonesia.

Furthermore, the student admit by the interview that "I use English because I could get punishment from the lecturer if I do not speak with it". This means the students use English just because of the compulsory task. Again, the statement from one of the participant on the interview that "using English with my lecturers because I don't want to feel ashamed; and by speaking English with my lecturers they can correct me if I'm wrong because they have better English than me". Whatever the reasons, all these depict the positive attitude of using English.

Referring to the topics (formal and informal) — speaking with friends only few students use English in non-formal topic and most of them use Bahasa Indonesia or even local languages. On the other hand, most students use English in formal topic and few use 
Bahasa Indonesia in which this is also confirmed by the interviewee that "I think I often use Bahasa Indonesia or may be local languages outside the classroom or for informal topic, because I just follow the one who speak such languages surrounding me". This is not surprising since Bahasa Indonesia and local languages are the lingua franca in Indonesia; even the local languages which are inclusively daily spoken inside the community.

\section{CONCLUSION}

To conclude, there are two important points emphasized from this research. First, in terms of language attitude the students have the positive attitude toward English. Though the students are not really confident on using English, but they want to do their best to use that language. They know the importance of mastering English skills and the importance of using English in either verbal communication or classroom activities. Meanwhile, in terms of language choice, English is the most language used by students in the academic environment and Bahasa Indonesia is the most language used outside the academic environment. The students are not able to maintain English as a common language use outside the classroom. Although they regard themselves can choose to speak English in the informal contexts, but they still maintain Bahasa Indonesia outside the classroom activities, especially when talking with friends, and even few of them still use their vernaculars.

The researcher realizes that this research article is far from perfect since it is very limited to its findings. It is only to observe the language attitude and language choice of the students inside the classroom context, but it does not investigate the reasons behind their attitudes and choices. The future researchers may investigate the concrete and valid factors of the students' language attitude and language choice in more specific things.

\section{REFERENCES}

Baker, C. (1992). Attitude and Language. UK: Multilingual Matters.

Bernstain, B. (2003). Class Codes and Control: Theoritical Studies towards a Sociology of Language. New York: Routledge.

Brown, H.D. (2000). Principles of Language Learning and Teaching. USA: San Fransisco State University.

Coulmas, F. (2013). Sociolinguistics: The Stidy of Speakers' Choices. Cambridge: Cambridge University Press.

Dewi, U. P. \& Setiadi, C.J. (2018). Language Attitude and Language Choice in Bilingual Academic Learning Environment. Lingua Cultura 12(4).

Dweik, B. S., \& Qawar, H. A. (2015). Language Choice And Language Attitudes In A Multilingual Arab Canadian Community: Quebec- Canada:A Sociolinguistic Study. .British Journal of English Linguistics Vol. 3 No.1.

Fishman, J. A. (1972). The Sociology of Language: An Interdisciplinary Social Science Approach to Language in Society. Newbury: Rowley. 
Fitriati, A. \&Wardani, M. M. S. (2019). Language Attitude and Language Choice among Students in Yogyakarta. Change and Preservatin in Language and Culture in Asia Fifth Edition.

Gardner, R. C. (1985). Social Psychology and Second Language Learning: The Role of Attitudes and Motivation Volume 4. London: Edward Arnold

Gonzalez, Virginia. (2004). Second Language Learning: Cultural Adaptation Process in International Graduate Students in U.S Universities. Oxford: University Press of America.

Holmes, J. \& Wilson, N. (2017). An introduction to Sociolinguistics Fifth Edition. New York: Routledge

Lambert, W. (1967). A Social Psychology of Bilingualism. Journal of Social Issues 23.

Thomson, S. G. (2001). Language Contact: An Introduction. Edinburgh: EUP. 